\title{
Methanococcus vulcanius sp. nov., a novel hyperthermophilic methanogen isolated from East Pacific Rise, and identification of Methanococcus sp. DSM 4213' as Methanococcus fervens sp. nov.
}

\author{
C. Jeanthon, ${ }^{1}$ S. L'Haridon, ${ }^{1}$ A.-L. Reysenbach, ${ }^{2}$ E. Corre, ${ }^{1}$ M. Vernet, ${ }^{1}$ \\ P. Messner, ${ }^{3}$ U. B. Sleytr ${ }^{3}$ and D. Prieur ${ }^{1,4}$
}

Author for correspondence: C. Jeanthon. Tel: +33 298292309. Fax: +33298292324.

e-mail: jeanthon@sb-roscoff.fr

\footnotetext{
1 Station Biologique, UPR9042, Centre National de la Recherche

Scientifique and Université

Pierre et Marie Curie,

Place Georges-Teissier,

29680 Roscoff, France

2 Department of

Biochemistry and

Microbiology,

Cook College,

Rutgers University,

New Brunswick, NJ 08903, USA

3 Zentrum für

Ultrastrukturforschung und Ludwig BoltzmannInstitut für Molekulare Nanotechnologie, Universităt für

Bodenkultur, 1180 Wien, Austria

4 Université de Bretagne Occidentale, UFR des Sciences et Techniques, 6 avenue Victor Le Gorgeu, 29285 Brest cedex, France
}

\begin{abstract}
An autotrophic, hyperthermophilic methanogen (M7') was isolated from a deep-sea hydrothermal chimney sample collected on the East Pacific Rise at a depth of $2600 \mathrm{~m}$. The coccoid-shaped cells are flagellated and exhibit a slight tumbling motility. The temperature range for growth at pH 6.5 was $49-89^{\circ} \mathrm{C}$, with optimum growth at $80^{\circ} \mathrm{C}$. The optimum pH for growth was 6.5 , and the optimum $\mathrm{NaCl}$ concentration for growth was around $25 \mathrm{~g} \mathrm{I}^{-1}$. The new isolate used $\mathrm{H}_{2}$ and $\mathrm{CO}_{2}$ as the only substrates for growth and methane production. Tungsten, selenium and yeast extract stimulated growth significantly. In the presence of $\mathrm{CO}_{2}$ and $\mathrm{H}_{2}$, the organism reduced elemental sulphur to hydrogen sulphide. Growth was inhibited by chloramphenicol and rifampicin, but not by ampicillin, kanamycin, penicillin and streptomycin. The $G+C$ content of the genomic DNA was $31 \mathrm{~mol} \%$. As determined by 165 rDNA gene sequence analysis, this organism was closely related to Methanococcus jannaschii strain JAL-1T. However, despite the high percentage of similarity between their 165 rDNA sequences (97.1\%), the DNA-DNA hybridization levels between these strains were less than $5 \%$. On the basis of these observations and physiological traits, it is proposed that this organism should be placed in a

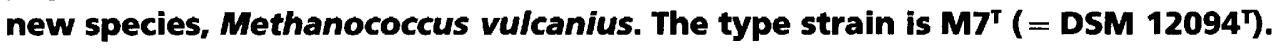
During the course of this study, the 165 rDNA sequence analysis placed Methanococcus sp. strain AG86 (= DSM 4213') as a close relative of $M$. jannaschii strain JAL-1'. However, the weak level of DNA-DNA hybridization with this strain $(<10 \%)$ allowed the proposal that strain $A^{-18}{ }^{\top}$ also constitutes a new species, Methanococcus fervens.
\end{abstract}

Keywords: deep-sea hydrothermal vents, thermophiles, Archaea, Methanococcus, Methanococcus vulcanius

\section{INTRODUCTION}

Within the order Methanococcales, the family Methanococcaceae contains one genus, Methanococcus, which is composed of eight species of mesophilic and thermophilic organisms (Burggraf et al., 1990; Whit-

\footnotetext{
The GenBank accession numbers for the 165 rDNA sequences of Methanococcus vulcanius $\mathrm{M7}^{\top}$ and Methanococcus fervens AG86 ${ }^{\top}$ are AF051404 and AF056938, respectively.
}

man et al., 1992; Jeanthon et al., 1998). The methanococci appear to be restricted to marine environments. Methanococcus vannielii was isolated from mud in San Francisco Bay (Stadtman \& Barker, 1951). A number of strains of Methanococcus voltae and Methanococcus maripaludis were isolated from estuarine and salt marsh sediments (Balch et al., 1979; Jones et al., 1983a; Whitman et al., 1986). The source of 'Methanococcus aeolicus' has not been reported. Two strains of Methanococcus thermolithotrophicus were isolated from coastal geothermally heated sediments close to 
Naples (Italy) (Huber et al., 1982) and from reservoir water from a North Sea oilfield (Nilsen \& Torsvik, 1996). The selenium-independent hyperthermophilic methanogen Methanococcus igneus was isolated from a shallow submarine hydrothermal vent (Kolbeinsey ridge, Iceland) (Burggraf et al., 1990). Furthermore, Methanococcus jannaschii and Methanococcus infernus have been isolated from deep-sea hydrothermal vents from the East Pacific Rise at $21^{\circ} \mathrm{N}$ and Mid-Atlantic Ridge at $23^{\circ} \mathrm{N}$ (Jones et al., 1983b; Jeanthon et al., 1998). Close relatives to $M$. jannaschii that included strain AG86 ${ }^{\mathrm{T}}$ were also obtained from deep-sea sediments at Guaymas Basin (Zhao et al., 1988; Jones et al., 1989; Canganella \& Jones, 1994). Physiological characteristics of strain AG86 ${ }^{\mathrm{T}}$ have been described and phenotypic and chromosomal differences with $M$. jannaschii have been observed (Zhao et al., 1988). As part of this paper, we confirm that strain AG86 constitutes a new species using DNA-DNA hybridization and 16S rDNA phylogenetic analysis. Additionally, we report the isolation and characterization of a novel hyperthermophilic Methanococcus sp. isolated from a deep-sea hydrothermal vent chimney collected at $13^{\circ} \mathrm{N}$ on the East Pacific Rise.

\section{METHODS}

Source of organisms. The new strain was isolated from a chimney sample collected from the $13^{\circ} \mathrm{N}$ hydrothermal field $\left(12^{\circ} 48^{\prime} \mathrm{N}, 103^{\circ} 56^{\prime} \mathrm{W}\right)$ during the 'Hero' cruise (1991), on the East Pacific Rise at a depth of $2600 \mathrm{~m}$. Methanococcus infernus strain $\mathrm{ME}^{\mathrm{T}}$ (DSM 11812 ${ }^{\mathrm{T}}$ ) was isolated by our laboratory (Jeanthon et al., 1998). Methanococcus jannaschii strain $\mathrm{JAL}^{\mathrm{T}}{ }^{\mathrm{T}}\left(\mathrm{DSM} 2661^{\mathrm{T}}\right)$, Methanococcus sp. strain AG86 $^{\mathrm{T}}$ (DSM 4213 ), Methanococcus igneus strain Kol $5^{\mathrm{T}}$ (DSM 5666 ${ }^{\mathrm{T}}$ ) and Methanococcus thermolithotrophicus strain SN-1 ${ }^{\mathrm{T}}$ (DSM 2095 ${ }^{\mathrm{T}}$ ) were obtained from the Deutsche Sammlung von Mikroorganismen und Zellkulturen (Braunschweig, Germany).

Enrichment, isolation and growth conditions. Enrichments were performed anaerobically in $50 \mathrm{ml}$ or $100 \mathrm{ml}$ vials containing 10 or $20 \mathrm{ml}$ medium, respectively (Miller \& Wolin, 1974). The enrichment and culture medium consisted of (per litre distilled water): $30 \mathrm{~g}$ sea salts (Sigma), $1 \mathrm{~g}$ $\mathrm{NH}_{4} \mathrm{Cl}, 0.35 \mathrm{~g} \mathrm{KH}_{2} \mathrm{PO}_{4}, 3.46 \mathrm{~g}$ PIPES, $1 \mathrm{~g} \mathrm{NaHCO}, 2 \mathrm{~g}$ Difco yeast extract, $0.5 \mathrm{~g}$ cysteine. $\mathrm{HCl}, 1 \mathrm{ml}$ trace element mixture (Widdel \& Bak, 1992), $30 \mathrm{mg}$ tungstate, $0.5 \mathrm{mg}$ selenate, $1 \mathrm{ml}$ vitamin mixture (Widdel \& Bak, 1992), $1 \mathrm{ml}$ thiamin solution (Widdel \& Bak, 1992), 0.05 mg vitamin $\mathbf{B}_{12}$, $1 \mathrm{ml}$ growth-stimulating factors (Pfennig et al., 1981) and $1 \mathrm{mg}$ resazurin. The $\mathrm{pH}$ was adjusted to 6.5 using $1 \mathrm{M} \mathrm{HCl}$ before autoclaving, and the medium was reduced by adding $\mathrm{Na}_{2} \mathrm{~S} .9 \mathrm{H}_{2} \mathrm{O}$ (final concentration of $0.05 \%$, w/v). $\mathrm{H}_{2} / \mathrm{CO}_{2}$ $[80: 20 ; 200 \mathrm{kPa}$ (above atmospheric pressure)] was used as the gas phase. Unless indicated otherwise, cultures were incubated at $80^{\circ} \mathrm{C}$, and the $\mathrm{pH}$ of the medium was readjusted after $1 \mathrm{~h}$ incubation. Single colonies were obtained and purified by streaking on the same medium that was reduced with a titanium(III) citrate solution (Zehnder \& Wuhrman, 1976) and solidified with $0.7 \%$ (w/v) Phytagel (a gellan gum from Sigma). Plates were incubated in anaerobic jars at $75^{\circ} \mathrm{C}$ for $3 \mathrm{~d}$ under a $\mathrm{H}_{2} / \mathrm{CO}_{2}$ atmosphere $(80: 20$; $300 \mathrm{kPa}$ ). Stock cultures of the isolate $\mathrm{M}^{\mathrm{T}}$ were stored in culture medium at $4{ }^{\circ} \mathrm{C}$. For long-term storage, pure cultures were stored at $-80{ }^{\circ} \mathrm{C}$ in the same medium containing $20 \%$ (w/v) glycerol.

Determination of growth. Growth was monitored by measuring the increase in $\mathrm{OD}_{600}$ with a Spectronic $20 \mathrm{D}$ spectrophotometer (Bioblock). Direct cell counts were determined using cells stained with acridine orange and epifluorescence microscopy using an ocular grid (Hobbie et al., 1957). All growth experiments were performed in duplicate.

Determination of growth parameters. The $\mathrm{pH}$ range for growth was determined in the culture medium with various buffers at a concentration of $10 \mathrm{mM}$; acetate/acetic acid buffer for $\mathrm{pH} 4-5$, MES for $\mathrm{pH} 5.5$ and 6.0, PIPES buffer for $\mathrm{pH} 6.5$ and 7.0, HEPES buffer for $\mathrm{pH} \mathrm{7.5,} \mathrm{Tris} \mathrm{for} \mathrm{pH} 8$ and $8 \cdot 5$. The $\mathrm{pH}$ of the medium was adjusted after $1 \mathrm{~h}$ incubation at the optimal temperature for growth. The effect of $\mathrm{NaCl}$ on growth was determined in the same medium containing 0 , $1 \cdot 25,2 \cdot 5,3 \cdot 75,5 \cdot 0,6 \cdot 25$ and $7 \cdot 5 \%(\mathrm{w} / \mathrm{v}) \mathrm{NaCl}$. The effects of $\mathrm{pH}$ and concentration of $\mathrm{NaCl}$ were determined at the optimal temperature for growth.

Determination of growth requirements. The ability of the organism to utilize substrates other than $\mathrm{H}_{2}$ was tested by using the culture medium without yeast extract amended with autoclaved or filter-sterilized substrates (see below). $\mathrm{N}_{2} / \mathrm{CO}_{2}(80: 20 ; 200 \mathrm{kPa})$ was used as the gas phase. Acetate $\left(2 \mathrm{~g} \mathrm{l}^{-1}\right)$, formate $\left(5 \mathrm{~g} \mathrm{l}^{-1}\right)$, methanol $(0 \cdot 5 \%, \mathrm{v} / \mathrm{v})$, monomethylamine $\left(2 \mathrm{~g} \mathrm{l}^{-1}\right)$ and yeast extract $\left(2 \mathrm{~g} \mathrm{l}^{-1}\right)$ were also tested as possible carbon sources in the medium without bicarbonate by using $\mathrm{H}_{2}(100 \% ; 200 \mathrm{kPa})$ as the gas phase. Selected nitrogenous compounds were tested for suitability as nitrogen sources using ammonium-free mineral medium (Widdel \& Bak, 1992). Nitrogenous compounds were added at $10 \mathrm{mM}$ final concentration. Sulphur $\left(5 \mathrm{~g} \mathrm{l}^{-1}\right)$, thiosulphate $(20 \mathrm{mM})$ and sulphate $(20 \mathrm{mM})$ were tested as potential electron acceptors in the same mineral medium where $\mathrm{NH}_{4} \mathrm{Cl}$ $\left(0.35 \mathrm{~g} \mathrm{l}^{-1}\right)$ was added but sulphate was omitted. To determine their potential stimulatory effects on the growth yield, the vitamin mixture, trace element solution, yeast extract, tungstate and selenate were tested individually in the basal medium that consisted of (per litre distilled water): 30 g sea salts, $1 \mathrm{~g} \mathrm{NH}_{4} \mathrm{Cl}, 0.35 \mathrm{~g} \mathrm{KH}_{2} \mathrm{PO}_{4}, 3.46 \mathrm{~g}$ PIPES, $1 \mathrm{~g}$ $\mathrm{NaHCO}_{3}, 0.5 \mathrm{~g}$ cysteine. $\mathrm{HCl}$ and $1 \mathrm{mg}$ resazurin. The $\mathrm{pH}$ was adjusted as before, and $\mathrm{H}_{2} / \mathrm{CO}_{2}(80: 20 ; 200 \mathrm{kPa})$ was used as the gas phase.

Antibiotic susceptibility. Sensitivity of strains $M 7^{\mathrm{T}}$ and AG86 ${ }^{\mathrm{T}}$ to chloramphenicol $\left(75 \mu \mathrm{g} \mathrm{ml}^{-1}\right)$, penicillin $\mathrm{G}(200 \mu \mathrm{g}$ $\left.\mathrm{ml}^{-1}\right)$, streptomycin $\left(200 \mu \mathrm{g} \mathrm{ml}^{-1}\right)$, kanamycin $\left(200 \mu \mathrm{g} \mathrm{ml}^{-1}\right)$, ampicillin $\left(200 \mu \mathrm{g} \mathrm{ml}^{-1}\right)$ and rifampicin $\left(50 \mu \mathrm{g} \mathrm{ml}^{-1}\right)$ (all from Sigma) was tested at $80^{\circ} \mathrm{C}$. Simultaneous experiments were performed with the thermophilic methanogens $M$. infernus strain $\mathrm{ME}^{\mathrm{T}}, M$. jannaschii strain $\mathrm{JAL}-1^{\mathrm{T}}$ and $M$. igneus strain Kol $5^{\mathrm{T}}$ at $80^{\circ} \mathrm{C}$ and $M$. thermolithotrophicus strain $\mathrm{SN}-1^{\mathrm{T}}$ at $65^{\circ} \mathrm{C}$.

Light and electron microscopy. An Olympus BH-2 microscope equipped with an Olympus OM-2 camera was used routinely to observe and count the cells. For negative staining, $20 \mu \mathrm{l}$ bacterial suspension fixed with $2 \%(\mathrm{w} / \mathrm{v})$ glutaraldehyde was dropped on Formvar/carbon-coated grids (400 mesh) and stained with $4 \%(\mathrm{w} / \mathrm{v})$ uranyl acetate. Preparation of cells for freeze-fracturing and ultrathin sectioning was performed as described previously (Sleytr et al., 1988). Electron micrographs were taken using a model CM100 electron microscope (Philips) with an acceleration voltage of $80 \mathrm{kV}$.

$\mathrm{H}_{2} \mathrm{~S}$ production. $\mathrm{H}_{2} \mathrm{~S}$ production was evaluated by adding $500 \mu \mathrm{l}$ of a solution of $\mathrm{CuSO}_{4}(5 \mathrm{mM})$ and $\mathrm{HCl}(50 \mathrm{mM})$ to 
$250 \mu \mathrm{l}$ culture grown at $85^{\circ} \mathrm{C}$. The dark-brown precipitate demonstrating the presence of sulphide was compared to that of the uninoculated medium incubated under the same conditions.

Methane determination. Methane was measured with a Girdel model 3000 gas chromatograph equipped with a thermal conductivity detector. Samples $(0.5 \mathrm{ml})$ were injected onto a Poropak Q (80-100 mesh) column and eluted with helium at a flow rate of $12 \mathrm{ml} \mathrm{min} \mathrm{m}^{-1}$. Temperatures were as follows: injector, ambient temperature; column, $60{ }^{\circ} \mathrm{C}$; detector, $150^{\circ} \mathrm{C}$. These conditions allowed us to follow the methane production and hydrogen consumption simultaneously.

DNA extraction and base composition. Genomic DNA of strain $\mathrm{M}^{\mathrm{T}}$ was isolated by using the procedure described by Charbonnier \& Forterre (1994). The DNA was purified on a caesium chloride gradient (Sambrook et al., 1989), and purity was checked spectrophotometrically. The $\mathrm{G}+\mathrm{C}$ content of the DNA was determined from the melting point according to Marmur \& Doty (1962) using Escherichia coli DNA $(52 \mathrm{~mol} \% \mathrm{G}+\mathrm{C}$; Sigma), Clostridium perfringens DNA (24 mol \% G+C; Sigma) and Micrococcus luteus DNA ( $73 \mathrm{~mol} \% \mathrm{G}+\mathrm{C}$; Sigma) as standards.

PCR amplification and sequencing of 165 rDNA. The $16 \mathrm{~S}$ rDNA was amplified by PCR as described previously (Reysenbach et al., 1992). The double-strand PCR products were sequenced with an ABI 373 automated sequencer. The $16 \mathrm{~S}$ rDNA sequences were aligned manually with a representative set of $16 \mathrm{~S}$ rRNA sequences obtained from the Ribosomal Database Project (Maidak et al., 1996) and from recent GenBank releases. The GenBank accession numbers for the 16S rRNA sequences reported in this paper are as follows: $M$. infernus $\mathrm{ME}^{\mathrm{T}}$, AF025822; $M$. jannaschii JAL- ${ }^{\mathrm{T}}$, M59126; $M$. thermolithotrophicus SN-1 ${ }^{\mathrm{T}}$, M59128; M. igneus Kol 5', M59125; $M$. voltae PS', M59290; and ' $M$. aeolicus' A, U39016. The secondary structure was used as a guide to ensure that only homologous regions were compared. A total of 1424 (strain M7 $7^{\mathrm{T}}$ ) and 1400 (strain $A G 86^{\mathrm{T}}$ ) nucleotides were sequenced and 1377 were used in the phylogenetic analysis. Distance trees were constructed by the least-squares algorithm of De Soete (1983). Maximumlikelihood trees and corresponding bootstrap proportions were constructed using the program fastDNAml (Olsen $e t$ al., 1994). Bootstrap values were obtained for 100 replicate trees.

DNA hybridization. Genetic relatedness was investigated by slot-blot DNA-DNA hybridization by using a randomprime labelling and signal amplification system (Amersham Life Sciences) following the procedure described by Kristjánsson et al. (1994). Increasing amounts of target DNA (50-100 ng) denatured in $0.4 \mathrm{M} \mathrm{NaOH}$ were slotted onto a nylon hybridization membrane (Bio-Rad) and probed with $200 \mathrm{ng}$ labelled tracer DNA. For each duplicate of DNA-DNA reassociation $(15 \mathrm{~h}$ in buffer $4 \times$ SSC with formamide, $0.5 \%$ blocking agent, $5 \%$ dextran sulphate, $100 \mu \mathrm{g}$ denatured sheared salmon sperm DNA ml ${ }^{-1}$ ), the temperature of hybridization chosen was in the optimal range of the hybridization buffer (Johnson, 1984; Ivanova et al., 1988). Final high stringent washes and signal amplification were performed according to the manufacturer's instructions. Hybridization signals were detected with a Storm fluorescent scanner (Molecular Dynamics) and analysed by using the IMAGE-QUANT program. Signal (maximum peak area) produced by self-hybridization of the probe with homologous target DNA was set as $100 \%$ and compared with the signal generated by heterologous DNA.

\section{RESULTS}

\section{Enrichment and isolation}

To enrich for methanogenic thermophiles, $10 \mathrm{ml}$ enrichment medium was inoculated with approximately $1 \mathrm{ml}$ of a chimney suspension. The enrichments were incubated at $80^{\circ} \mathrm{C}$ in $50 \mathrm{ml}$ vials with $\mathrm{H}_{2} / \mathrm{CO}_{2}$ as the gas phase $(80: 20 ; 200 \mathrm{kPa})$ without shaking. Within 2-3 d, turbidity due to cell growth was observed. This growth consisted of motile coccoid cells that fluoresced intense green at $420 \mathrm{~nm}$. Pure cultures were obtained by streaking subcultures onto solidified culture medium and incubating in an anaerobic jar with the same gas phase at $75^{\circ} \mathrm{C}$. On solid medium, pale-yellow round colonies ( $1 \mathrm{~mm}$ in diameter) were visible after incubation for up to $3 \mathrm{~d}$. One colony was randomly picked and was designated isolate $M 7^{\mathrm{T}}$.

\section{Morphology}

Cells of strain $M 7^{\mathrm{T}}$ were irregular cocci, about 1-3 $\mu \mathrm{m}$ in diameter (Fig. 1a). Ultrathin sections of whole cells of strain $\mathrm{M}^{\mathrm{T}}$ possessed the typical archaeal cell envelope profile consisting of the cytoplasmic membrane and a single surface layer (S-layer) (Fig. 1b). They occurred singly or in pairs (Fig. 1a) and exhibited tumbling motility with three tufts of flagella, each tuft containing a large number of flagella (Fig. 1c). Since the strain was heavily flagellated, flagella were observed even in thin sections (Fig. 1b). The methods used to prepare the cells for freeze-fracturing did not allow us to recognize an S-layer lattice. From our experience, we know that the S-layer proteins are so delicate that the discrete lattice is disrupted during preparation. The cells were markedly fragile and readily lysed by detergents (in 1-2 min with $0.01 \%$ SDS or $N$-lauroylsarcosine) or by distilled water.

\section{Determination of growth parameters}

Strain $M 7^{\mathrm{T}}$ grew between 49 and $89^{\circ} \mathrm{C}$ with optimum growth around $80^{\circ} \mathrm{C}$, while no growth was detected at 48 and $90^{\circ} \mathrm{C}$ (Fig. 2a). Growth was observed between $\mathrm{pH} 5.25$ and $7 \cdot 0$, with optimum growth around $\mathrm{pH} 6.5$ (data not shown). Growth occurred in $\mathrm{NaCl}$ concentrations ranging from $6 \cdot 25$ to $56 \cdot 25 \mathrm{~g} \mathrm{l}^{-1}$ (Fig. 2b), with optimum growth at $25 \mathrm{~g} \mathrm{l}^{-1}$. No growth was observed at 3.1 and $62.5 \mathrm{~g} \mathrm{l}^{-1}$. Under optimal growth conditions (temperature, $\mathrm{pH}$ and $\mathrm{NaCl}$ ) the doubling time of strain $M 7^{\mathrm{T}}$ was approximately $45 \mathrm{~min}$.

\section{Determination of growth requirements}

Strain $M 7^{\mathrm{T}}$ is a strictly anaerobic autotrophic organism. Its growth is prevented in the presence of low levels of oxygen, and $\mathrm{H}_{2}+\mathrm{CO}_{2}$ serve as the only substrates for growth. No growth was observed on acetate, formate, methanol, monomethylamine or yeast extract with an $\mathrm{N}_{2} / \mathrm{CO}_{2}(80: 20 ; 200 \mathrm{kPa})$ or $\mathrm{H}_{2}$ $(100 \% ; 200 \mathrm{kPa})$ headspace. As a control, $M$. thermo- 

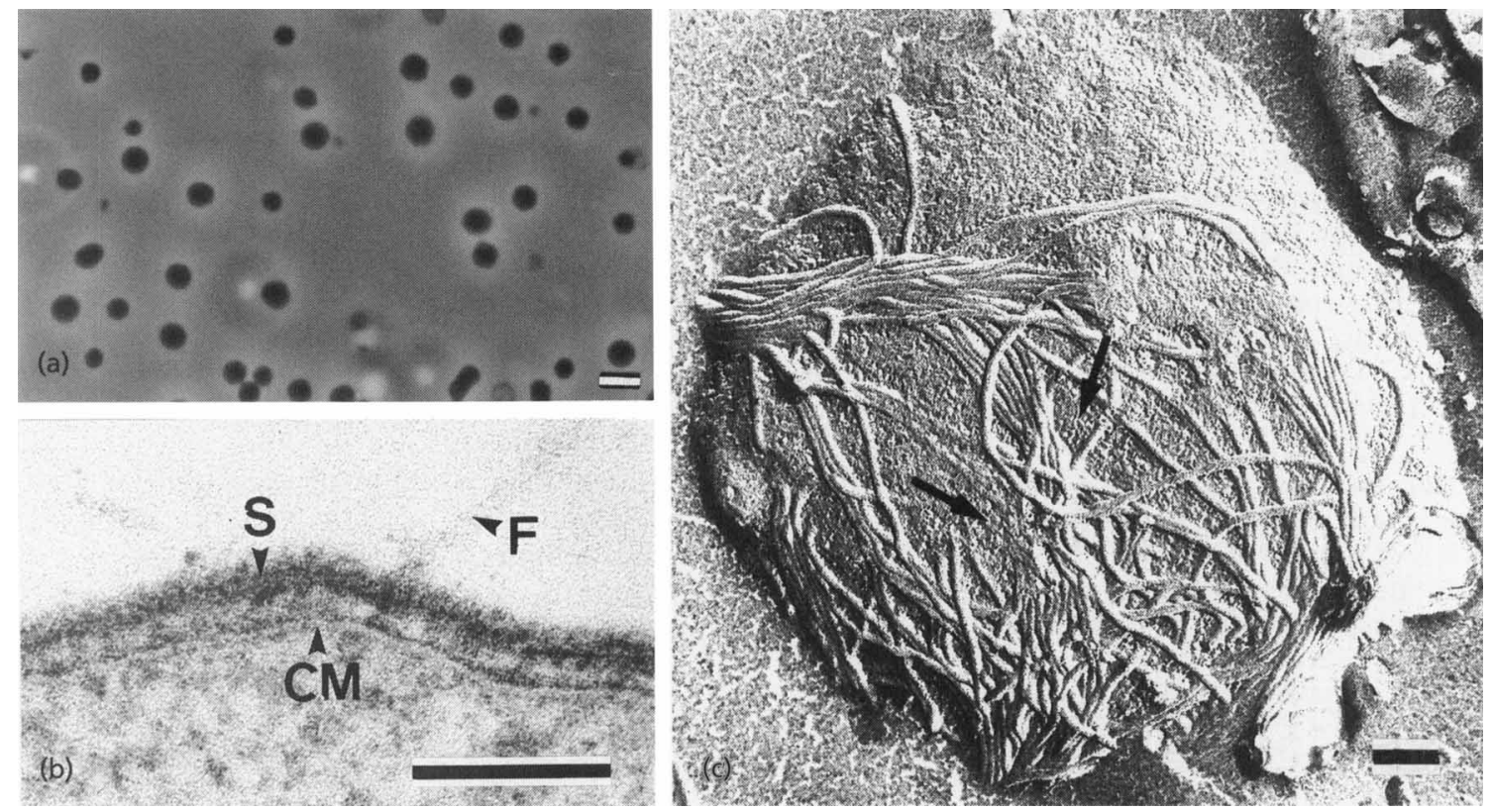

(b)

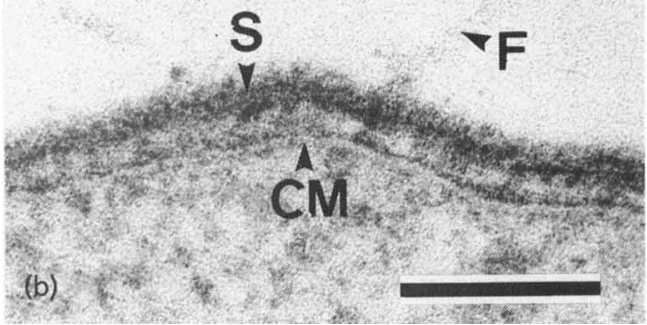

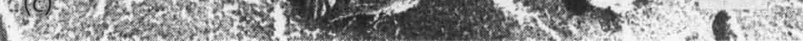

Fig. 1. Phase-contrast micrograph (a) of strain $M 7^{\top}$ (bar, $5 \mu \mathrm{m}$ ) and electron micrographs $(b, c)$ of strain $M 7^{\top}$. Ultrathin sections (b) of whole cells showed the typical archaeal cell envelope profile; bar, $100 \mathrm{~nm}$. S, S-layer; CM, cytoplasmic membrane; F, flagellum. Freeze-etched and shadowed preparations (c) showed the flagella and the S-layer. Arrows indicate the presence of the S-layer lattice; bar, $100 \mathrm{~nm}$.

lithotrophicus strain $\mathrm{SN}-1^{\mathrm{T}}$ grew on formate at $65^{\circ} \mathrm{C}$ in the presence of $\mathrm{N}_{2} / \mathrm{CO}_{2}$. In the presence of $\mathrm{H}_{2}$ and $\mathrm{CO}_{2}$, growth was accompanied by exponential methane production which paralleled growth (data not shown). Large amounts of methane (up to $32 \mu \mathrm{mol}$ $\mathrm{ml}^{-1}$ ) were produced when cells entered in the stationary phase (12 h incubation). Ammonium was preferably used as nitrogen source but significant growth also occurred in the presence of nitrate (data not shown). When supplemented individually in the basal medium, the vitamin mixture, tungstate solution, selenate solution and yeast extract stimulated the growth yield by two- to threefold. Final cell densities (two to three times lower than the control) revealed that the trace element solution was slightly inhibitory (data not shown). When sulphur was added to the medium in the presence of $\mathrm{CO}_{2}$ and $\mathrm{H}_{2}$, growth occurred and $\mathrm{H}_{2} \mathrm{~S}$ was produced. No dissimilatory reduction of sulphate and thiosulphate was observed.

\section{Sensitivity to antibiotics}

Strain $\mathrm{M}^{\mathrm{T}}$, strain $\mathrm{AG}^{\mathrm{T}} \mathrm{6}^{\mathrm{T}}$, M. jannaschii strain JAL$1^{\mathrm{T}}, M$. igneus strain $\mathrm{Kol} 5^{\mathrm{T}}, M$. infernus strain $\mathrm{ME}^{\mathrm{T}}$ and $M$. thermolithotrophicus strain $\mathrm{SN}-1^{\mathrm{T}}$ were resistant to ampicillin and kanamycin $\left(200 \mu \mathrm{g} \mathrm{ml}^{-1}\right)$ and were sensitive to chloramphenicol $\left(75 \mu \mathrm{g} \mathrm{ml} \mathrm{ml}^{-1}\right)$. Among these strains, only $M$. thermolithotrophicus strain $\mathrm{SN}-1^{\mathrm{T}}$ was inhibited by penicillin and streptomycin $\left(200 \mu \mathrm{g} \mathrm{ml}^{-1}\right)$. Finally, $M$. jannaschii strain $\mathrm{JAL}-1^{\mathrm{T}}, M$. infernus strain $\mathrm{ME}^{\mathrm{T}}$ and strain $\mathrm{M} 7^{\mathrm{T}}$ were sensitive to rifampicin $\left(50 \mu \mathrm{g} \mathrm{m}{ }^{-1}\right)$ whereas strain $\mathrm{AG86}^{\mathrm{T}}, M$. igneus strain Kol $5^{\mathrm{T}}$ and $M$. thermo- lithotrophicus strain $\mathrm{SN}-1^{\mathrm{T}}$ were resistant to this compound at the same concentration.

\section{DNA base composition}

The $\mathrm{G}+\mathrm{C}$ content of the DNA of strain $\mathrm{M}^{\mathrm{T}}$ determined by the thermal denaturation method was $31 \mathrm{~mol} \%$. As a control, the base composition of Fervidobacterium nodosum was determined to be $35 \mathrm{~mol} \%$ [ $34 \mathrm{~mol} \%$ by the $T_{\mathrm{m}}$ method reported by Patel et al. (1985) and by direct base analysis reported by Huber et al. (1990)].

\section{5 rDNA sequence analysis}

16S rDNA sequence analysis placed strain $\mathrm{M} 7^{\mathrm{T}}$ as a close relative of $M$. jannaschii strain JAL- $1^{\mathrm{T}}(97 \cdot 6 \%$ similarity), strain AG86 ${ }^{\mathrm{T}}(96.9 \%$ similarity) and $M$. infernus (95.7\% similarity) (Fig. 3). Strain AG86 showed the highest similarity to the 16S rDNA sequence of $M$. jannaschii $(97 \cdot 7 \%)$. Phylogenetic trees generated using distance algorithms or maximumlikelihood analysis gave the same topology. The bootstrap values from 100 samplings confirmed the affiliation of strain $M 7^{\mathrm{T}}$ to a clade (monophyletic taxon) that also included $M$. jannaschii strain JAL- ${ }^{\mathrm{T}}$, strain $\mathrm{AG} 86^{\mathrm{T}}$ and $M$. infernus strain $\mathrm{ME}^{\mathrm{T}}$.

\section{DNA-DNA hybridization}

No significant hybridization was obtained between bulk cellular DNA of the isolate $\mathrm{M}^{\mathrm{T}}$ and that from M. jannaschii strain JAL- $1^{\mathrm{T}}(<5 \%)$, strain AG86 ${ }^{\mathrm{T}}$ 


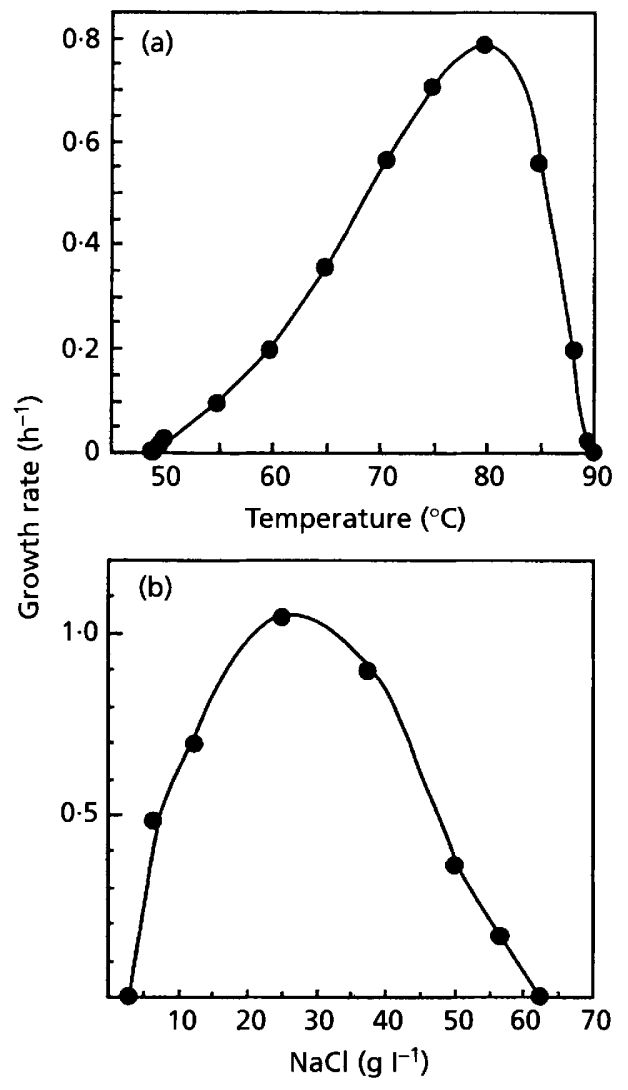

Fig. 2. Growth rates $(\mu)$ of strain $M 7^{\top}$ as a function of temperature (a) in the presence of $\mathrm{NaCl}\left(25 \mathrm{~g} \mathrm{l}^{-1}\right)$ at $\mathrm{pH} 6.5$ and as a function of concentration of $\mathrm{NaCl}$ (b) at $80^{\circ} \mathrm{C}$ and at $\mathrm{pH}$ 6.5. Growth was followed $\left(\mathrm{OD}_{600}\right)$ in the culture medium under an atmosphere of $\mathrm{H}_{2} / \mathrm{CO}_{2}(80: 20 ; 200 \mathrm{kPa})$.

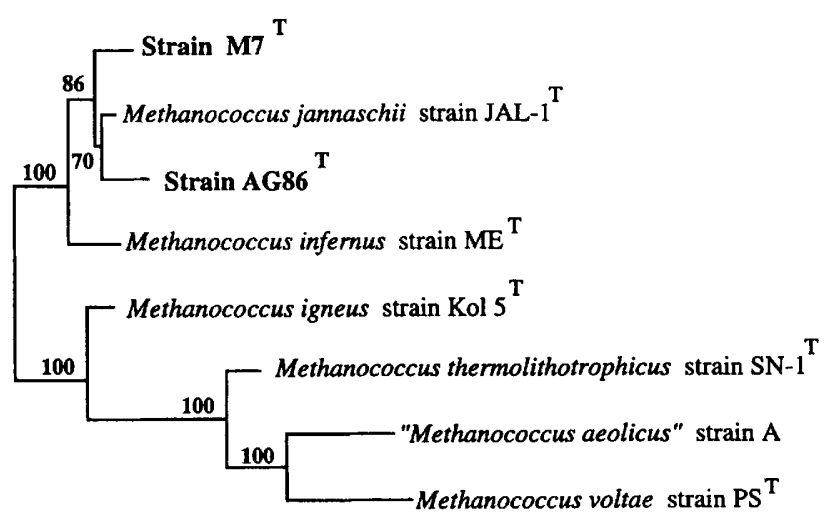

0.10

Fig. 3. Phylogenetic relationship of strains $M 7^{\top}$ and $A G 86^{\top}$ and other Methanococcales produced by maximum-likelihood analysis. The sequence of the $M 7^{\top}$ small subunit was aligned with other rRNAs from the Ribosomal Database Project (Maidak et al., 1996). The scale bar represents the expected number of changes per sequence position. and $M$. infernus strain $\mathrm{ME}^{\mathrm{T}}(<2 \%)$. Moreover, the distinct species status of strain AG86 ${ }^{\mathrm{T}}$ was demonstrated by weak levels of DNA-DNA hybridization with $M$. jannaschii strain JAL- ${ }^{\mathrm{T}}(<10 \%), M$. infernus strain $\mathrm{ME}^{\mathrm{T}}(<2 \%)$ and $\mathrm{M}^{\mathrm{T}}(<2 \%)$.

\section{DISCUSSION}

The novel marine hyperthermophilic strain $M 7^{\mathrm{T}}$ belongs to the domain Archaea on the basis of the cell envelope composition, its resistance to antibiotics and the 16S rDNA sequence (Hilpert et al., 1981; Woese et al., 1990; Sleytr et al., 1996). The morphology, metabolism, $\mathrm{G}+\mathrm{C}$ content and the $16 \mathrm{~S}$ rDNA sequence indicate that strain $M 7^{\mathrm{T}}$ belongs to the genus Methanococcus.

Strain $M 7^{\mathrm{T}}$ differs from $M$. thermolithotrophicus strain $\mathrm{SN}-1^{\mathrm{T}}$ in its inability to use formate and in its temperature range and optimum for growth (Table 1) (Huber et al., 1982; Jones et al., 1989). It differs from $M$. igneus strain $\mathrm{Kol} 5^{\mathrm{T}}$ in its motility, its temperature optimum for growth, its ability to grow in the presence of sulphur and its positive response to the effect of yeast extract and selenium (Burggraf et al., 1990). The newly described strain $M 7^{\mathrm{T}}$ is most similar to $M$. jannaschii strain $\mathrm{JAL}-1^{\mathrm{T}}$, strain $\mathrm{AG} 86^{\mathrm{T}}$ and $M$. infernus strain $\mathrm{ME}^{\mathrm{T}}$ with respect to motility, temperature range for growth (Table 1) and susceptibility to antibiotics. However, strain $M 7^{\mathrm{T}}$ is distinct from the above strains by its optimum temperature for growth and by other slight differences. Contrary to $M$. infernus strain $\mathrm{ME}^{\mathrm{T}}$, strain $\mathrm{M} 7^{\mathrm{T}}$ can grow below $55^{\circ} \mathrm{C}$, but not at $90^{\circ} \mathrm{C}$. The flagellar system of strain JAL- $1^{\mathrm{T}}$ consists of two bundles of flagella inserted close to the same pole (Jones et al., 1983b) whereas that of strain $\mathrm{M}^{\mathrm{T}}$ appears to be arranged in three tufts of flagella, two of them inserted in polar positions. As reported for $M$. infernus strain $M E^{\mathrm{T}}$, the growth of strain $M 7^{\mathrm{T}}$ and of $A G 86^{\mathrm{T}}$ in basal medium was enhanced by the presence of yeast extract. Yeast extract has no stimulatory effect on growth of strain JAL- $1^{\mathrm{T}}$ (Jones et al., 1983b; Jeanthon et al., 1998).

The $16 \mathrm{~S}$ rDNA analysis indicated that $\mathrm{M} 7^{\mathrm{T}}$ is closely related to other deep-sea vent methanococci isolates, namely $M$. jannaschii, strain $\mathrm{AG} 86^{\mathrm{T}}$ and $M$. infernus strain $\mathrm{ME}^{\mathrm{T}}$. However, a low level of genetic relationship between strains $\mathrm{M}^{\mathrm{T}}, \mathrm{ME}^{\mathrm{T}}, \mathrm{AG} 86^{\mathrm{T}}$ and $\mathrm{JAL}-1^{\mathrm{T}}$ was determined by DNA-DNA hybridization studies, indicating that these organisms cannot be assigned to the same species (Johnson, 1984). Similarly, weak levels of DNA-DNA hybridization were measured between $M$. jannaschii strain $\mathrm{JAL}-1^{\mathrm{T}}$ and strain $\mathrm{AG}^{\mathrm{T}}{ }^{\mathrm{T}}$. Phenotypically, strain AG86 ${ }^{\mathrm{T}}$ was distinct from $M$. jannaschii strain JAL- $1^{\mathrm{T}}$ by its $\mathrm{pH}$ range for growth (Table 1) and in its response to the stimulatory effects on growth of Casamino acids and yeast extract (Zhao et al., 1988). Here, we determined that AG86 ${ }^{\mathrm{T}}$ was resistant to rifampicin $\left(50 \mu \mathrm{g} \mathrm{ml}^{-1}\right)$ whereas $M$. jannaschii strain $\mathrm{JAL}-1^{\mathrm{T}}$ was sensitive. 
Table 1. Characteristics of Methanococcus species and strains $M 7^{\top}$ and $A G 86^{\top}$

\begin{tabular}{|c|c|c|c|c|c|c|c|c|}
\hline \multirow[t]{2}{*}{ Organism } & \multicolumn{2}{|c|}{ Temp. $\left({ }^{\circ} \mathrm{C}\right)$} & \multirow[t]{2}{*}{ pH range } & \multicolumn{3}{|c|}{ Stimulatory compounds } & \multirow{2}{*}{$\begin{array}{l}\text { Resistance to } \\
\text { rifampicin* }\end{array}$} & \multirow[t]{2}{*}{ Reference } \\
\hline & Range & Optimum & & Se & $\mathrm{WO}_{4}$ & $\begin{array}{c}\text { Yeast } \\
\text { extract }\end{array}$ & & \\
\hline Strain $M 7^{\mathrm{T}}$ & $49-89$ & 80 & $5 \cdot 25-7 \cdot 0$ & + & + & + & - & This work. \\
\hline Strain AG86 ${ }^{\mathrm{T}}$ & $48-92$ & 85 & $5 \cdot 50-7 \cdot 6$ & + & + & + & + & Zhao et al. (1988) \\
\hline$M$. infernus strain $\mathrm{ME}^{\mathrm{T}}$ & $55-91$ & 85 & $5 \cdot 25-7 \cdot 0$ & + & + & + & - & Jeanthon et al. (1998) \\
\hline$M$. jannaschii strain JAL- $1^{\mathrm{T}}$ & $50-86 \dagger$ & 85 & $5 \cdot 20-7 \cdot 0$ & + & ND $\ddagger$ & - & - & Jones et al. $(1983 b)$ \\
\hline M. igneus strain Kol $5^{\mathrm{T}}$ & $45-91$ & 88 & $5 \cdot 00-7 \cdot 5$ & - & ND & + & + & Burggraf et al. (1990) \\
\hline $\begin{array}{l}\text { M. thermolithotrophicus } \\
\text { strain } \mathrm{SN}-1^{\mathrm{T}}\end{array}$ & $30-70$ & 65 & $6 \cdot 00-8 \cdot 0$ & ND & - & ND & + & Huber et al. (1982) \\
\hline
\end{tabular}

ND, Not determined.

* This test was performed in this study. The concentration tested was $50 \mu \mathrm{g} \mathrm{ml}^{-1}$. + , Resistant; - , sensitive.

$\dagger$ In our laboratory, the maximum growth temperature measured was $91{ }^{\circ} \mathrm{C}$. No growth was obtained at $93{ }^{\circ} \mathrm{C}(\mathrm{Jeanthon}$ et al., 1998 ).

In our laboratory, tungstate $\left(30 \mathrm{mg} \mathrm{l}^{-1}\right)$ was found to stimulate growth.

From the above results, we concluded that strain $\mathrm{M}^{\mathrm{T}}$ and strain $\mathrm{AG}^{\mathrm{T}} \mathrm{T}^{\mathrm{T}}$ represent new Methanococcus species. We propose to name strain $\mathrm{M} 7^{\mathrm{T}}$ as Methanococcus vulcanius and strain AG86 ${ }^{\mathrm{T}}$ as Methanococcus fervens, reflecting their high temperature of growth and the nature of their extreme habitat, the deep-sea hydrothermal vents.

\section{Description of Methanococcus vulcanius sp. nov.}

Methanococcus vulcanius (vul.ca'ni.us. L. masc. adj. vulcanius referring to Vulcanus, the Roman fire god, and to the place of isolation, the deep-sea hydrothermal vents).

Cells exhibit a tumbling motility by means of three tufts of flagella. They are cocci (diameter $1-3 \mu \mathrm{m}$ ) and occur singly and in pairs. Pale-yellow round colonies about $1 \mathrm{~mm}$ in diameter formed on 'Phytagel' plates. Growth occurs between 49 and $89^{\circ} \mathrm{C}$, with an optimum around $80^{\circ} \mathrm{C}$ (doubling time $45 \mathrm{~min}$ ). Growth occurs between $\mathrm{pH} 5.25$ and 7 with an optimum of approximately $\mathrm{pH} 6.5$ and with $\mathrm{NaCl}$ concentrations between 6.25 and $56.25 \mathrm{~g} \mathrm{l}^{-1}$ with an optimum of $25 \mathrm{~g}$ $1^{-1}$. Obligately anaerobic. Chemolithotrophic. Uses $\mathrm{H}_{2}$ and $\mathrm{CO}_{2}$ as energy and carbon sources to produce methane. Growth is stimulated by selenate, tungstate and yeast extract. Sulphur is reduced to hydrogen sulphide in the presence of $\mathrm{CO}_{2}$ and $\mathrm{H}_{2}$. Growth is inhibited by chloramphenicol $\left(75 \mu \mathrm{g} \mathrm{ml} \mathrm{m}^{-1}\right)$ and rifampicin $\left(50 \mu \mathrm{g} \mathrm{ml}^{-1}\right)$ but not by streptomycin, penicillin $\mathrm{G}$, kanamycin or ampicillin (all at $200 \mu \mathrm{g} \mathrm{ml}^{-1}$ ). DNA base composition of the type strain is $31 \mathrm{~mol} \%$ $\mathrm{G}+\mathrm{C}$ (as determined by the thermal denaturation method). The type strain is Methanococcus vulcanius $\mathbf{M} 7^{\mathrm{T}}$, which was obtained from a deep-sea hydrothermal vent chimney on the East Pacific Rise $\left(13^{\circ} \mathrm{N}\right)$. Strain $\mathrm{M} 7^{\mathrm{T}}$ has been deposited in the Deutsche Sammlung von Mikroorganismen und Zellkulturen as DSM $12094^{\mathrm{T}}$.

\section{Description of Methanococcus fervens sp. nov.}

Methanococcus fervens (fer'vens. L. part. adj. fervens boiling hot, referring to its high growth temperature).

Cells exhibit a tumbling motility. They are regular to irregular cocci (diameter 1-2 $\mu \mathrm{m}$ ) and occur singly and in pairs. Whitish, translucent and round colonies about $0.5 \mathrm{~mm}$ in diameter formed on Gelrite plates. Growth occurs between 48 and $92^{\circ} \mathrm{C}$, with an optimum around $85^{\circ} \mathrm{C}$ (doubling time 20-30 min). Growth occurs between $\mathrm{pH} 5.5$ and 7.6 with an optimum about $\mathrm{pH} 6.5$ and with $\mathrm{NaCl}$ concentrations between 0.5 and $5 \%$ $(\mathrm{w} / \mathrm{v})$ with an optimum of approximately $3 \%$. Obligately anaerobic. Chemolithotrophic. Uses $\mathrm{H}_{2}$ and $\mathrm{CO}_{2}$ as energy and carbon sources to produce methane. Growth is stimulated by yeast extract, Casamino acids, trypticase, selenite and tungstate. Growth is inhibited by chloramphenicol $\left(75 \mu \mathrm{g} \mathrm{ml}^{-1}\right)$ but not by streptomycin, penicillin $G$, kanamycin or ampicillin (all at $\left.200 \mu \mathrm{g} \mathrm{ml}^{-1}\right)$ or rifampicin $\left(50 \mu \mathrm{g} \mathrm{ml}^{-1}\right)$. DNA base composition of the type strain is $33 \mathrm{~mol} \% \mathrm{G}+\mathrm{C}$ (as determined by the thermal denaturation method). The type strain is Methanococcus fervens AG86 ${ }^{\mathrm{T}}$, which was obtained from a deep-sea hydrothermal vent core sample from Guaymas Basin, Gulf of California, at a depth of $2003 \mathrm{~m}$. Strain AG86 ${ }^{\mathrm{T}}$ is deposited in the Deutsche Sammlung von Mikroorganismen und Zellkulturen as DSM $4213^{\mathrm{T}}$.

\section{ACKNOWLEDGEMENTS}

The excellent technical assistance of Hélène Fouché, Mark Speck, Andrea Scheberl and Monika Miksa is gratefully acknowledged. We wish to thank Daniel Desbruyères, chief scientist of the 'Hero' cruise, organized by IFREMER, for inviting one of us to participate in that cruise.

This work performed at Roscoff was supported by CNRS, GDR 1006 CNRS/Ifremer, CPER 94-95 (Contrat de Plan Etat-Région), Fonds Structurel Européen (FEDER 5b) and MASTIII program. Grants from the Austrian Science 
Foundation, project S7201-MOB (to P.M.), and the Austrian Federal Ministry of Science and Transportation supported the work performed at Vienna.

\section{REFERENCES}

Balch, W. E., Fox, G. E., Magrum, L. J., Woese, C. R. \& Wolfe, R. S. (1979). Methanogens: re-evaluation of a unique biological group. Microbiol Rev 43, 260-296.

Burggraf, S., Fricke, H., Neuner, A., Kristjansson, J., Rouviere, P., Mandelco, L., Woese, C. R. \& Stetter, K. O. (1990). Methanococcus igneus sp. nov., a novel hyperthermophilic methanogen from a shallow submarine hydrothermal system. Syst Appl Microbiol 13, 33-38.

Canganella, F. \& Jones, W. J. (1994). Microbial characterization of thermophilic Archaea isolated from the Guaymas Basin hydrothermal vent. Curr Microbiol 28, 299-306.

Charbonnier, F. \& Forterre, P. (1994). Comparison of plasmid DNA topology among mesophilic and thermophilic eubacteria and archaebacteria. $J$ Bacteriol 176, 1251-1259.

De Soete, G. (1983). A least squares algorithm for fitting additive trees to proximity data. Psychometrika 48, 621-626.

Hilpert, R., Winter, J., Hammes, W. \& Kandler, O. (1981). The sensitivity of archaebacteria to antibiotics. Zentbl Bakteriol Hyg 1 Abt Orig C2, 11-20.

Hobbie, J. E., Daley, R. J. \& Jasper, S. (1977). Use of Nuclepore filters for counting bacteria by fluorescence microscopy. Appl Environ Microbiol 33, 1225-1228.

Huber, H., Thomm, M., König, H., Thies, G. \& Stetter, K. O. (1982). Methanococcus thermolithotrophicus, a novel thermophilic lithotrophic methanogen. Arch Microbiol 132, 47-50.

Huber, R., Woese, C. R., Langworthy, T. A., Kristjansson, J. K. \& Stetter, K. O. (1990). Fervidobacterium islandicum sp. nov., a new extremely thermophilic eubacterium belonging to the "Thermotogales'. Arch Microbiol 154, 105-111.

Ivanova, T. L., Turova, T. P. \& Antonov, A. S. (1988). DNA-DNA hybridization studies on some purple non sulfur bacteria. Syst Appl Microbiol 10, 259-263.

Jeanthon, C., L'Haridon, S., Reysenbach, A. L., Vernet, M., Messner, P., Sleytr, U. B. \& Prieur, D. (1998). Methanococcus infernus sp. nov., a novel hyperthermophilic lithotrophic methanogen isolated from a deep-sea hydrothermal vent. Int J Syst Bacteriol 48, 913-919.

Johnson, J. L. (1984). DNA reassociation and RNA hybridisation of bacterial nucleic acids. In Bergey's Manual of Systematic Bacteriology, vol. 1, pp. 8-11. Edited by N. R. Krieg \& J. G. Holt. Baltimore: Williams \& Wilkins.

Jones, W. J., Paynter, M. J. B. \& Gupta, R. (1983a). Characterization of Methanococcus maripaludis sp. nov., a new methanogen isolated from salt marsh sediment. Arch Microbiol 135, 91-97.

Jones, W. J., Leigh, J. A., Mayer, F., Woese, C. R. \& Wolfe, R. S. (1983b). Methanococcus jannaschii, sp. nov., an extremely thermophilic methanogen from a submarine hydrothermal vent. Arch Microbiol 136, 254-261.

Jones, W. J., Stugard, C. E. \& Jannasch, H. W. (1989). Comparison of thermophilic methanogens from submarine hydrothermal vents. Arch Microbiol 151, 314-318.

Kristjánsson, J. K., Hjörleifsdóttir, S., Marteinsson, V. T. \& Alfredsson, G. A. (1994). Thermus scotoductus, sp. nov., a pigment- producing thermophilic bacterium from hot tap water in Iceland and including Thermus sp. X-1. Syst Appl Microbiol 17, 44-50.

Maidak, B. L., Olsen, G. J., Larsen, N., Overbeek, R., McCaughey, M. J. \& Woese, C. R. (1996). The Ribosomal Database Project. Nucleic Acids Res 24, 82-85.

Marmur, J. \& Doty, D. (1962). Determination of the base composition of deoxyribonucleic acid from its thermal denaturation temperature. J Mol Biol 5, 109-118.

Miller, T. L. \& Wolin, M. J. (1974). A serum bottle modification of the Hungate technique for cultivating obligate anaerobes. Appl Environ Microbiol 27, 985-987.

Nilsen, R. K. \& Torsvik, T. (1996). Methanococcus thermolithotrophicus isolated from North Sea oil field reservoir water. Appl Environ Microbiol 62, 728-731.

Olsen, G. J., Matsuda, H., Hagstrom, R. \& Overbeek, R. (1994). fastDNAml: a tool for construction of phylogenetic trees of DNA sequences using maximum likelihood. Comput Appl Biosci 10, 41-48.

Patel, B. K. C., Morgan, H. W. \& Daniel, R. M. (1985). Fervidobacterium nodosum gen. nov. and spec. nov., a new chemoorganotrophic, caldoactive, anaerobic bacterium. Arch Microbiol 141, 63-69.

Pfennig, N., Widdel, F. \& Trüper, H. G. (1981). The dissimilatory sulfate-reducing bacteria. In The Prokaryotes, 2nd edn, pp. 926-940. Edited by M. Starr, H. Stolp, H. G. Trüper, A. Balows \& H. G. Schlegel. New York: Springer.

Reysenbach, A.-L., Giver, L. J., Wickham, G. S. \& Pace, N. R. (1992). Differential amplification of rRNA by polymerase chain reaction. Appl Environ Microbiol 58, 3417-3418.

Sambrook, J., Fritsch, E. F. \& Maniatis, T. (1989). Molecular Cloning : a Laboratory Manual, 2nd edn. Cold Spring Harbor, NY: Cold Spring Harbor Laboratory.

Sleytr, U. B., Messner, P. \& Pum, D. (1988). Analysis of crystalline bacterial surface layers by freeze-etching, metal-shadowing, negative staining and ultrathin sectioning. Methods Microbiol 20, 29-60.

Sleytr, U. B., Messner, P., Pum, D. \& Sára, D. (1996). Crystalline Bacterial Cell Surface Proteins. London: Academic Press.

Stadtman, T. C. \& Barker, H. A. (1951). Studies on the methane fermentation. X. A new formate-decomposing bacterium, Methanococcus vannieli. J Bacteriol 62, 269-280.

Whitman, W. B., Shieh, J., Sohn, S., Caras, D. S. \& Premachandran, U. (1986). Isolation and characterization of 22 mesophilic methanococci. Syst Appl Microbiol 7, 235-240.

Whitman, W. B., Bowen, T. L. \& Boone, D. R. (1992). The methanogenic bacteria. In The Prokaryotes, 2nd edn, pp. 719-767. Edited by A. Balows, H. G. Trüper, M. Dworkin, W. Harder \& K. H. Schleifer. New York: Springer.

Widdel, F. \& Bak, F. (1992). Gram-negative mesophilic sulfatereducing bacteria. In The Prokaryotes, 2nd edn, pp. 3352-3378. Edited by A. Balows, H. G. Trüper, M. Dworkin, W. Harder \& K. H. Schleifer. New York: Springer.

Woese, C. R., Kandler, O. \& Wheelis, M. L. (1990). Towards a natural system of organisms: proposal for the domain Archaea, Bacteria, and Eucarya. Proc Natl Acad Sci USA 87, 4576- 4579.

Zehnder, A. J. B. \& Wuhrman, K. (1976). Titanium(III) citrate as a non-toxic, oxidation-reduction buffering system for the culture of obligate anaerobes. Science 194, 1165-1166.

Zhao, H., Wood, A. G., Widdel, F. \& Bryant, M. P. (1988). An extremely thermophilic Methanococcus from a deep-sea hydrothermal vent and its plasmid. Arch Microbiol 150, 178-183. 